\title{
The Efficiency of Extensive Reading Project (ERP) in an Iranian EFL Context
}

\author{
Ali Asghar Kargar \\ Department of English, Islamic Azad University, Abadeh Branch, Iran \\ Email: Kargar928@Gmail.com
}

\begin{abstract}
The importance of input and exposure to simplified language for low level learners has been the focus of a lot of attention as a way to facilitate the process of language learning and acquisition. One way to help such learners is to have them read many simplified texts in the Language, a method which is called extensive reading. Many studies have shown the effectiveness of such programs in improving learners' reading proficiency. The main goal of the present study was to examine the effects of Extensive Reading Project on Iranian low level learners. To find its effects, of 67 EFL students who had failed their first reading course, 40 students were selected randomly and were divided randomly into one experimental and one control group. A standard reading proficiency test (pre-test) confirmed the homogeneity of both groups. Then during a program which took ten weeks to be accomplished, participants of the experimental group were asked to read ten interesting stories in English as a part of their reading class, while the members of control group continued their traditional reading class. At the end, the same standard reading proficiency test, as post-test, was introduced to both control and experimental groups. The obtained results revealed that there was a significant difference between the performances of both groups; in other words, extensive reading (ER) had a positive effect on the reading proficiency achievement of low level EFL students.
\end{abstract}

Index Terms - Extensive Reading Project (ERP), simplified language, low level learners, EFL students

\section{INTRODUCTION}

Reading in a foreign or a second language is usually a slow and tough task (Anderson,1999; Jensen,1986; Segalowitz, Poulsen \& Komoda, 1991); on the other hand, its role as a valuable and immediate source of input for language learners especially foreign language learners can not be neglected. The issue is more critical for low-level learners as Nuttel (1996, p.127) introduces a "vicious circle" to refer to the learners who fail in maintaining an acceptable command of reading comprehension ability. Low-level learners do not read much, and if they do not read much, their reading skill will not improve. If they fail to improve their reading comprehension, they can not enjoy reading, leading to frustration and disappointment. Consequently the problem for low-level readers is at least bi-dimensional: lack of needed language competence and lack of motivation.

The value of Extensive Reading Program (ERP) has been confirmed as a program to enhance both motivation and reading comprehension as well as general language competence in various contexts. For example Krashen (1995) define the program as the one in which learners "do self-selected reading with only minimal accountability, writing brief summaries on what they have read" (192). Also with extensive reading, learners are exposed to "large quantities of materials within their linguistic competence" (Grabe \& Stoller, 1997, p. 102) at the same time "pleasurable" (Pigada \& Schmitt, 2006; Taguchi \& Gorsuch, 2002).

Based on "comprehensible input hypothesis", Kerashen (1984) argues that extensive reading can facilitate language learning mostly because the program is graded based on learners' self - perceived level. Since input or the texts are easy enough for the learners to understand, it may break our ugly "vicious circle", resulting in generating enough motivation to read more and more and to be a better reader. Extensive reading, as a result, in line with Kerashen's hypothesis, offers a large number of graded interesting materials in a relaxed and anxiety-free learning environment.

Extensive reading (ER) can improve general language competence especially in FL contexts where sources of authentic input are more limited (Gebhard, 1996; Redfield, 1999). Extensive Reading is said to improve learners' fluency - the ability to automatically recognize an increasing number of words and phrases, especially and effectively involved in comprehension of L2 texts (Grabe, 1991; Paren, 1996; Perfetti, Van Dyke \& Hart, 2001). Elley (1991) perceives ER as a way to fill "the exposure gap" between L1 and L2 language input (p.404). Based on several studies, he concluded that there was "a spread of effect from reading competence to other language skills - writing, speaking and control over syntax." According to Day and Bamford (1998) through authentic reading, L2 and FL readers can acquire both linguistic and world knowledge to improve their reading skills.

ER can enhance vocabulary knowledge. Based on the results of a study done by Nagy, Herman and Anderson (1985), more words can be learnt from getting the students to spend time on silent reading of interesting books than controlled introducing number of new words in each class. In a recent study by Pigada and Schmitt (2006), the effect of extensive 
reading on vocabulary acquisition were examined and the results supported the effectiveness of the method. The study suggested that spelling was strongly enhanced during ER.

It can improve writing. Both L1 studies (Krashen, 1984; Stotsky, 1983) and L2 studies of ERP in different situations such as Hafiz and Tudor (1990) in UK and Pakistan and Robb and Susser (1989) showed the significant improvement of learners' written work in addition to other language skills.

ER can be effective in increasing learners' motivation. By definition in extensive reading, texts are graded and selected based on the learners present level, so their ability to accomplish the task is to a great extent guaranteed. The topics are selected by the learners themselves; they can choose the ones they enjoy; as a result, reading will be both motivating and interesting. In a study to enhance reading motivation and habits, Bell and Campbell (1996) concluded that extensive reading was the most effective way among various ways to motivate learners to read. Motivation as Ellis (1994) states, "affects the extent to which individual learners persevere in learning the L2 and the kind of learning behavior they employ, and their actual involvement" (p.36). ER can help to build confident readers. Kembo (1993) studied the effect of ER on developing students' confidence and ability in reading long texts. The results of the study were confirming as expected.

ER can encourage both textual knowledge and background knowledge and help learners use metacognitive as well as cognitive strategies while reading. Learners can exploit background knowledge, use pre - existing schema and decode and interpret the message of the text more easily (Nunan, 1991).

To sum up, ER has several goals including encouraging L2 learners to read for pleasure and information both inside and outside classroom, to read for meaning and to engage in sustained silent reading (Day \& Bamford, 1998; Krashen, 1995). The results of the studies have shown its effectiveness in increasing reading speed and comprehension as well as overall language development (Bell, 2001; Rub \& Susser, 1989; Elley \& Mangubhai, 1983). Consequently, the present study aims at investigating the efficiency of ERP in an Iranian EFL context in terms of improving Iranian learners' reading comprehension.

\section{RESEARCH QUESTION}

The present study was designed to investigate whether an extensive reading program (ERP) has the potential to improve low level learners' reading comprehension in an Iranian EFL context. More specifically, the following research question was formulated for this study:

Q: Does extensive reading (ERP) have the potential to enhance low level learners' reading comprehension in an Iranian EFL context?

\section{METHODOLOGY}

\section{A. Participants}

The participants were drawn from Iranian students majoring English at Islamic Azad University of Abadeh. Of 67 EFL students who had failed their first reading comprehension course, 40 students were randomly selected and were assigned randomly and equally to one control and one experimental group. In the experimental group, twelve students were female, and eight students were male. In the control group, eleven students were female, and nine students were female. The age range was from 19 to 22. As they had a very bad experience in their first attempt to read in English in an academic situation, they were in real need of improving their motivation and reading competence. None of them had previous experience of studying English in language institutes.

\section{B. Material}

Simplified graded readers were preferred for extensive reading because they could offer learners appropriate conditions for learning and increasing motivation as suggested by Nation and Wang (1999) and Wodinsky and Nation (1998).

Ten stories were selected based on their difficulty levels suggested by their publishers defined in terms of lexis and structure. All of them were paperback with glossy cover indicating the titles and the back cover giving descriptions and details of the series (stages and number of vocabulary presented). Illustration and pictures were used in most of them which helped learners both to understand and enjoy reading. The length and difficulty level varied from first to the tenth story. The information about the series and sequence of their presentation is summarized in the following table. 
TABLE 1.

DESCRIPTIVE INFORMATION OF THE STORIES

\begin{tabular}{|l|l|l|l|}
\hline NO. & NAME & LEVEL & Pages \\
\hline 1 & Island for Sale & Beginner (300 words) & 15 \\
\hline 2 & Michele Jordan & Beginner (300 words) & 17 \\
\hline 3 & Pele & Beginner (300 words) & 25 \\
\hline 4 & Little Women & Beginner (300 words) & 28 \\
\hline 5 & Love or Money & Beginner (300 words) & 35 \\
\hline 6 & Phantom of the Opera & Beginner (300 words) & 50 \\
\hline 7 & ET & Elementary(600 words) & 39 \\
\hline 8 & Tales of Anderson & Elementary(600 words) & 35 \\
\hline 9 & Brave Heart & Pre -intermediate (1200 words) & 41 \\
\hline 10 & The Railway Children & Pre -intermediate (1200 words) & 60 \\
\hline
\end{tabular}

In addition to the books, audio CDs including mp3 files of the stories were prepared and given to the learners. It was based on the prediction that they may find it difficult to read the text because of unfamiliar words, pronunciations and abbreviations. In addition, it is believed that reading and listening at the same time have great benefits for pronunciation (sound and symbol relationship) and increasing reading speed (Taguchi \& Gorsuch, 2002). Listening materials can provide the learners with a model of correct pronunciation which aids word recognition and expose them to correct intonation. It can help them maintain and elaborate their confidence by enabling them to produce natural speech patterns.

A standardized reading comprehension test designed by Isfahan University was also used for pre and post-test. The test includes six reading passages and forty multiple choice questions. The internal consistency of the test in the study was estimated .84 by using Cronbach's alpha.

\section{Data Collection Procedures}

The treatment of the study lasted more than ten weeks and comprised of three phases:

1. Pre-testing:

Before the students in experimental group received any treatment, all the students in two groups participated in a standardized reading proficiency test to determine their level of reading proficiency and assure the researchers that there is no significant difference between the control and experimental group. The results are indicated in the following table:

TABLE 2

INDEPENDENT SAMPLE T-TEST OF PRE-TESTS OF CONTROL \& EXPERIMENTAL GROUPS

\begin{tabular}{|l|l|l|l|l|l|l|l|}
\hline Groups & Test & N & Mean & SD & t & Df & Sig. \\
\hline experimental & Pre test & 20 & 17.72 & 6.64 & & 38 & .01 \\
control & Pre test & 20 & 16.15 & 5.38 & 0.82 & 38 \\
\hline
\end{tabular}

As it is shown in table 2, there is no significant between the two groups on their pre-tests, so the results confirm the homogeneity of the groups.

2. Treatment:

Following pre-testing, the participants of the experimental group received the list of 35 graded stories to choose ten most-liked ones. They had also the chance of changing the stories during the study if they felt they did not like them. The participants of the experimental group received the treatment as a part of their reading class, while the control group continued the traditional reading class. The program lasted 10 weeks during which the subjects were supposed to read the stories, each week one storybook. After they had read the stories, there was a discussion on each part of the story. Learners' questions about meaning or pronunciation of words and grammar of the sentences were answered. Some of them could not understand the meaning of some of the sentences, so the sentences were paraphrased for them. They were also advised to listen to the audio of the stories. Ten essay type questions followed the reading to ensure their comprehension. The questions were both information and inferential ones. After essay type questions, they listened to two parts of the story. Then they were asked to write the setting, place and time of the events. The rational behind the oral questions was to make them listen to the audio of the stories. The levels of the stories gradually were increasing. Meanwhile the students were being monitored for their reactions toward the stories and the program.

3. Post testing:

After the extensive reading treatment (at the conclusion of the treatment period) all the students in two groups again received the same standardized reading proficiency test as a post-test to see their overall reading improvement.

\section{RESULTS AND DisCUSSIONS}

Based on the data of pre- and post-tests introduced to both experimental and control group, attempts were made to find out whether an ER project can help low level learners improve their reading comprehension. For this purpose, a series of t-test analysis were used in three phases:

At first, a paired-sample t-test was used to find the possible change between the means of pre- and post-tests of the control group. The result is summarized in the following table: 
TABLE 3.

PAIRED SAMPLE T-TEST OF PRE- \& POST-TESTS OF CONTROL GROUP

\begin{tabular}{|l|l|l|l|l|l|l|l|}
\hline Groups & Test & N & Mean & SD & T & Df & Sig. \\
\hline control & Pre test & 20 & 16.15 & 5.38 & \multirow{2}{*}{19} & .01 \\
control & Post test & 20 & 16.63 & 7.17 & 0.24 & 19 \\
\hline
\end{tabular}

As shown, the mean of post-test is slightly greater than that of pre-test but the difference is not significant; so the students of the control group showed no significant achievement during the study.

Next, using the same procedure, the pre- and post-test scores of experimental group, as indicated in table 4, were analyzed:

TABLE 4.

PAIRED-SAMPLE T-TEST OF PRE- \& POST-TESTS OF EXPERIMENTAL GROUP

\begin{tabular}{|l|l|l|l|l|l|l|l|}
\hline Groups & Test & N & Mean & SD & t & Df & Sig. \\
\hline experimental & Pre test & 20 & 17.72 & 6.64 & \multirow{2}{*}{.01} & \\
experimental & Post test & 20 & 22.69 & 4.72 & 2.72 & .01 \\
\hline
\end{tabular}

The performance of the subjects on pre- and post-test is significantly different at .01 level of significance; in other words, the project has been effective in elaborating learners' reading comprehension.

Finally, the post-test performance of both control and experimental group were compared and the obtained results revealed that there is a significant difference between two groups in their post-test scores at .01 level of significance:

TABLE 5.

INDEPENDENT T-TEST OF POST-TESTS OF CONTROL \& EXPERIMENTAL GROUPS

\begin{tabular}{|l|l|l|l|l|l|l|l|}
\hline Groups & Test & N & Mean & SD & t & Df & Sig. \\
\hline experimental & Post test & 20 & 22.69 & 4.72 & & \multirow{2}{*}{.01} \\
control & Post test & 20 & 16.63 & 7.17 & 3.14 & .01 \\
\hline
\end{tabular}

As evident in table 5, extensive reading (ER) proved to have a positive effect on students' reading proficiency level.

\section{CONCLUSIONS}

Based on the previous researches on the effects of ERP on different language skills and sub - skills, the present study attempted to find the place of the ERP on Iranian learners specially those with low reading proficiency level. Forty learners were assigned randomly to control and experimental groups. The experimental group received a treatment by reading ten stories during a 10 week project. Every week they read one story preceded by a brief discussion on words, grammar and the main idea of the texts and followed by an essay type test to check their comprehension. The obtained results of the study showed that ERP can be beneficial for the learners specially those who have had hard time in reading foreign language texts. The results showed that ERP elaborates learners reading comprehension.

\section{Pedagogical Implications}

The conclusions drawn from the study have implications for both EFL teachers and learners.

For teachers, it shows the role input can play in improving learners' reading proficiency. The study proves that ERP can be a promising method to enhance learners reading proficiency and motivation. It can also be used as a good method to increase learners' vocabulary. The project can be used by teachers to break the learners' frustration and help them move forward. As learners improve their reading, they enjoy reading more and more. If they enjoy reading, their access to language input will increase dramatically, which will further promote their language development.

For learners, the results are heartening. It shows the way they can overcome their lack of motivation and fear they usually experience in the beginning of their way to learn a FL. It makes the difficult task of language learning an enjoyable time, full of fun and entertainment. Then the focus of their attention will be more on language rather than language learning.

\section{REFERENCES}

[1] Anderson, N. J. (1999). Exploring second language reading: Issues and strategies. Boston, MA: Heinle \& Heinle.

[2] Bell, T. \& Campbell, J. (1996). Promoting Good Reading Habits Part 2: The Role of Libraries. Network 2(4), 26 - 35.

[3] Bell, T. (2001). Extensive reading: Speed and comprehension. The Reading Matrix, 1 (1). Retrieved from www.readingmatrix.com/articles/bell/index.html on June 2007.

[4] Day, R. R. \& Bamford, J. (1998). Extensive reading in the second language classroom. New York: Cambridge University Press.

[5] Elley, W. B. (1991). Acquiring literacy in a second language: The effect of book-based programs. Language Learning, 4(3), $375-411$.

[6] Elley, W. B. \& Mangubhai, F. (1983). The impact of reading on second language learning. Reading Research Quarterly, 19(1), 53-67. 
[7] Ellis, R. (1994). The Study of Second Language Acquisition. Oxford: Oxford University Press.

[8] Gebhard, J. G. (1996). Teaching English as a foreign or second language. Ann Arbor, MI: University of Michigan Press.

[9] Grabe, W. (1991). Current developments in second language reading research. TESOL Quarterly, 25(3), 375-406.

[10] Grabe, W. \& Stoller, F. (1997). Reading and vocabulary development in a second language: A case study. In J. Coady \&at. Huckin (Eds.), Second language vocabulary acquisition: A rationale for Pedagogy (pp.98-122). Cambridge: Cambridge University Press.

[11] Hafiz, F. \& Tudor, I. (1990). Graded readers as an input medium in L2 learning. System, 18(1), 31-42.

[12] Jensen, L. (1986). Advanced reading skills in a comprehensive course. In F. Dubin, D. E. Eskey, \& W. Grabe (Eds.), Teaching second language reading for academic purposes (pp.103-124). Reading, MA: Addison-Wesley.

[13] Kembo, J. (1993). Reading: Encouraging and Maintaining Individual Extensive Reading. English Teaching Forum, 31(2), (3638).

[14] Krashen, S. (1984). Writing Research, Theory and Applications. New York: Prentice Hall.

[15] Krashen, S. (1995). Free voluntary reading: Linguistic and affective arguments and some new applications. In F. Eckman, D. Highland, P. Lee, J. Mileham \& R. Weber (Eds.), Second language acquisition theory and pedagogy (pp.187-202). Mahwah, NJ: Lawrence Erlbaum Associates.

[16] Nagy, W., Herman, P., \& Anderson, R. (1985). Learning words from context. Reading Research Quarterly, 20, $233-253$.

[17] Nation, I. S. P. \& Wang, K. (1999). Graded readers and vocabulary. Reading in a Foreign Language, 12(2), 355-380.

[18] Nunan, D. (1991). Language Teaching Methodology: A Textbook for Teachers. London: Prentice Hall.

[19] Nuttall, C. (1996). Teaching reading skills in a foreign language (2nd ed.) Oxford: Heinemann.

[20] Paran, A. (1996). Reading in EFL: Facts and fictions. English Language Teaching Journal, 50(1), 25-34.

[21] Perfetti, C., Van Dyke, J., \& Hart, L. (2001). The psycholinguistics of basic literacy. Annual Review of Applied Linguistics, 21, 127-149.

[22] Pigada, M. \& Schmitt, N. (2006). Vocabulary Acquisition from Extensive Reading: A Case Study. Reading in a Foreign Language. 18 (1)

[23] Redfield, M. (1999). Massive input through Eiga Shosetsu: A pilot study with Japanese learners. JALT Journal, 21(1), 51-65.

[24] Robb, T. N. \& Susser, B. (1989). Extensive reading vs skills building in an EFL context. Reading in a Foreign Language, 5(2), 239-251.

[25] Segalowitz, N., Poulsen, C., \& Komoda, M. (1991). Lower level components of reading skill in higher level bilinguals: Implications for reading instruction. AILA Review, 8(1), 15-30.

[26] Stotsky, S. (1983). Research on Reading / Writing Relationships: A Synthesis and Suggested Directions. Language Arts, 60, (627 - 642)

[27] Taguchi, E. \& Gorsuch, G. J. (2002). Transfer effects of repeated EFL reading o reading new passages: a preliminary Investigation. Reading in a Foreign Language, 14 (1), 43-45.

[28] Wodinsky, M. \& Nation, P. (1998). Learning from graded readers. Reading in a Foreign Language, 5(1), 155-161.

Ali Asghar Kargar is a PHD student in TEFL at Shiraz University, Iran. He has been a lecturer in the Department of English at Islamic Azad University, Abadeh branch. He has been teaching different courses in TEFL and English Translation for 10 years. His research interest includes teaching and testing language skills especially reading and writing as well as teaching methodology. He has also published a book in essay writing entitled "easy essay". 